\title{
PROJECT BASED LEARNING BERMUATAN ETNOMATEMATIKA DALAM PEMBELAJAR MATEMATIKA
}

\author{
I Wayan Eka Mahendra \\ Jurusan Pendidikan Matematika, \\ Institut Keguruan dan IImu Pendidikan PGRI Bali, Indonesia \\ E-mail: eka_undiksha@yahoo.com
}

\begin{abstract}
Abstrak
Tujuan utama penelitian ini adalah untuk mengetahui perbedaan secara simultan motivasi belajar dan hasil belajar matematika antara peserta didik yang mengikuti model pembelajaran project based learning bermuatan etnomatematika dan peserta didik yang mengikuti model pembelajaran konvensional pada siswa kelas VIII SMP Negeri 3 Abiansemal. Penelitian ini merupakan penelitian eksperimen semu dengan melibatkan sampel sebanyak 71 orang yang diambil dengan teknik simple random smpling. Data yang terkumpul dianalisis dengan menggunakan MANOVA satu jalur. Hasil penelitian ini menunjukkan bahwa perbedaan secara simultan motivasi belajar dan hasil belajar matematika antara peserta didik yang mengikuti model pembelajaran project based learning bermuatan etnomatematika dan peserta didik yang mengikuti model pembelajaran konvensional pada siswa kelas VIII SMP Negeri 3 Abiansemal. Disarankan untuk guru matematika SMP untuk memacu hasil belajar matematika. Guru juga perlu menggunakan model pebelajaran yang tepat dan akurat.
\end{abstract}

Keywords: model pembelajaran, motivasi, hasil belajar

\begin{abstract}
This study aims to determine differences simultaneously in motivation and mathematics learning outcomes between students taking project based learningmodel charged ethnomathematics and students who followed the conventional learning modelon the class VIII SMP Negeri 3 Abiansemalyear 2016/2017. It was a quasi experiment with a sample of 71 student obtain by using simple random sampling. The data were analyzed by one-way multivariate analysis (Manova). The results of this study indicate that there are differences in simultaneously in learning motivation and learning outcomes between students taking mathematics model project based learning charged ethnomathematics and students who followed the conventional learning model on the class VIII SMP Negeri 3 Abiansemal year 2016/2017. Besed on the research findings, junior high school teachers are suggested to improve their student learning outcome for mathematics. Teachers also need to use a learning models accurately and correctly.
\end{abstract}

Keywords: learning model, motivation, learning outcome.

\section{PENDAHULUAN}

Pendidikan adalah usaha sadar dan terencana untuk mewujudkan suasana belajar dan proses pembelajaran agar peserta didik secara aktif mengembangkan potensi dirinya untuk memiliki kekuatan spiritual keagamaan, pengendalian diri, kepribadian, kecerdasan, akhlak mulia, serta keterampilan yang diperlukan dirinya, masyarakat, bangsa dan negara (UU Sisdiknas, 2003). Dalam era kesemrawutan global, idealnya pendidikan tidak hanya berorientasi pada masa lalu dan masa kini. Pendidikan hendaknya melihat jauh kedepan dan memikirkan apa yang akan dihadapi peserta didik di masa yang akan datang. Di lain hal, globalisasi juga menjadi ancaman bagi budaya Indonesia. Indonesia mengalami degradasi (penurunan) dalam beragam bidang sehingga cenderung menjadi bangsa yang tidak mempunyai dignity 
(martabat), integritas, kejujuran, kecerdasan, dan kreativitas (Lisa, 2012). Pendidikan dan budaya memiliki peranan yang sangat penting dalam menumbuhkan dan mengembangkan nilai luhur bangsa. Penanamaan nilai budaya bisa dilakukan melalui lingkungan keluarga, pendidikan, dan lingkungan masyarakat sekitar, dengan mengaktifkan kembali segenap wadah dan kegiatan pendidikan. Selain sebagai pelestarian, pendidikan juga dapat menjadi sebuah gardu terdepan dalam kesuksesan sebuah negara.

Dalam dunia pendidikan, matematika merupakan mata pelajaran yang penting diajarkan pada setiap jenjang pendidikan, karena memberikan banyak manfaat dan dapat diterapkan dalam berbagai bidang kehidupan. Matematika merupakan ilmu tentang logika mengenai bentuk, susunan, besaran dan konsep-konsep yang berhubungan satu dengan yang lainnya (Rizka, 2014). Menurut Ismayani dan Nuryanti (2016), matematika diberikan mulai dari sekolah dasar untuk membekali peserta didik dengan kemampuan berpikir logis, analisis, sistematis, kritis, dan kreatif serta kemampuan bekerja sama. Kebutuhan masyarakat akan pemahaman matematika di era globalisasi ini akan terus meningkat, sehingga menuntut penguasaan pengetahuan maupun kemampuan baru. Begitu pentingnya peranan matematika dalam kehidupan masyarakat, seharusnya menjadikan matematika sebagai mata pelajaran yang menyenangkan dan digemari oleh peserta didik. Tidak dapat dipungkiri, banyak peserta didik di sekolah tidak menyukai pelajaran matematika. Peserta didik menganggap matematika adalah pelajaran yang paling sulit dan tidak mudah dipahami karena terdapat banyak hal yang perlu dipecahkan, dari rumus hingga menghafal atau mengartikan dalam bahasa matematikanya. Berbagai upaya telah dilakukan oleh pemerintah Indonesia seperti wajib belajar 9 tahun, beberapa fasilitas beasiswa pendidikan dan penunjang lainnya telah dilakukan. Namun, semua usaha tersebut belum membuahkan hasil yang optimal dan mutu pendidikan di Indonesia terlihat masih rendah dibandingkan dengan mutu pendidikan di negara lain.

Hasil studi PISA (Programme for Internasional Student Assessment) menunjukan bahwa peserta didik Indonesia kurang mampu menggunakan konsep-konsep matematika untuk menyelesaikan persoalan yang berhubungan dengan kehidupan nyata. Mereka sulit untuk mengerjakan persoalan matematika dalam bentuk proyek matematika. Hal ini dikarenakan selama ini siswa cenderung diajarkan rumus-rumus praktis yang nantinya digunakan untuk menyelesaikan soal ujian. Siswa merasa bosan apabila diberikan persoalan matematika dalam bentuk proyek, karena yang mereka inginkan adalah soal-soal matematika praktis yang bisa langsung diselesaikan dengan menggunakan beberapa rumus tanpa harus berpikir panjang.

Hal ini tidak jauh berbeda dengan apa yang terjadi di Bali. Hasil pengamatan beberapa sekolah di Bali menemukan bahwa rerata hasil ulangan harian siswa SMP adalah 55 dari rentangan 0 (nol) sampai denga 100. Jika dilihat pada terhadap pola jawaban ulangan harian siswa, diketahui bahwa kelemahan siswa terletak dalam hal: 1) membuat model matematika dari masalah yang diberikan; 2) memilih dan menetapkan strategi untuk menyelesaikan masalah; 3) sebagian besar hanya mampu melakukan perhitungan secara mekanis tetapi belum mampu menjelaskan atau menginterpretasikan hasil perhitungannya; 4) menjabarkan hasil perhitungan mekanis ke dalam penyelesaian masalah realistik; dan 5) membaca dengan pemahaman suatu representasi yang diberikan. Hal tersebut menunjukkan bahwa kemampuan siswa dalam pemecahan masalah dan komunikasi matematisnya masih kurang.

Selain masalah hasil belajar yang rendah, masalah lainnya dalam pembelajaran matematika di Bali adalah masalah motivasi belajar siswa yang rendah. Wawancara dengan siswa SMP 
di Abiansemal, $70 \%$ dari 40 orang siswa yang diwawancarai menyatakan malas belajar matematika. Siswa tampak tidak antusias dan kurang ceria dalam mengikuti pembelajaran matematika. Beberpa siswa bahkan terlihat mengantuk saat diberikan LKS (Lembar Kerja Siswa) oleh guru yang mengajar.

Hasil pengamatan lebih lanjut menemukan bahwa proses pembelajaran menjadi pemicu kuat rendahnya hasil belajar matematika siswa. Hal ini didukung oleh Widyantini (2014) yang menyatakan bahwa proses pembelajaran dikatakan dapat tercapai dengan baik, jika peserta didik dapat memahami materi yang dijelaskan oleh guru dan memiliki motivasi belajar. Guru harus menyadari betapa pentingnya motivasi belajar peserta didik, sebab peserta didik yang memiliki motivasi belajar akan lebih siap menghadapi semua pelajaran dari pada peserta didik yang tidak memiliki motivasi belajar.

Rendahnya motivasi belajar dan hasil belajar matematika peserta didik dikarenakan penggunaan model pembelajaran yang digunakan guru bersifat konvensional. Dalam pembelajaran konvensional guru hanya menjelaskan materi lalu memberi contoh soal dari buku dan terkadang hanya beberapa peserta didik yang mengerti akan materi yang dijelaskan oleh guru. Guru beranggapan jika sudah ada beberapa peserta didik yang mengerti materi yang dijelaskan oleh guru, maka itu sudah cukup mewakili peserta didik yang lainnya. Hal ini dikarenakan guru ingin menyelesaikan materi tepat waktu agar tidak ada materi yang tertinggal.

Proses pembelajaran yang monoton seperti itu kurang mendukung peserta didik untuk aktif dalam pembelajaran, sehingga peserta didik menjadi bosan dan malas dalam melatih diri untuk menjawab soal-soal jika tidak diperintah oleh guru. Peserta didik juga sangat sulit dalam mengaitkan antara materi yang diajarkan dan situasi dunia nyata. Ketika peserta didik dihadapkan pada suatu permasalahan, paling banyak peserta didik mengalami kesulitan dalam mengekspresikan atau mempresentasikan masalah, situasi, ide ke dalam model matematika atau gambar. Selain itu, peserta didik takut dan malu untuk bertanya atau menjawab pertanyaan dari guru. Bahkan dengan teman sebangku atau orang yang memiliki kemampuan yang lebih baik, mereka enggan untuk bertanya. Akibat pembelajaran konvensional yang diterapkan oleh guru, peserta didik yang awalnya masih semangat mengikuti pelajaran matematika, semangatnya menjadi menurun, kurang aktif, dan kurang kreatif. Peserta didik mengganggap matematika tidak penting dan tidak bermanfaat dalam kehidupan seharihari.

Sebagai upaya mengatasi permasalahan di atas, diperlukan model pembelajaran yang dapat membuat peserta didik aktif, dapat menggungkapkan ide-ide matematika dan dapat membangkitkan motivasi belajar. Salah satunya adalah model pembelajaran project based learning. Model pembelajaran project based learning atau pembelajaran berbasis proyek adalah model pembelajaran yang menggunakan proyek atau kegiatan sebagai media yang melibatkan peserta didik dalam mentransfer pengetahuan dan keterampilan melalui proses penemuan dengan serangkaian pertanyaan yang tersusun dalam tugas atau proyek (Ambarwati, 2015). Model Pembelajaran ini pada umumnya terkait dengan pembahasan permasalahan nyata. Pembelajaran berbasis proyek merupakan cara belajar yang menggunakan masalah sebagai langkah awal dalam mengumpulkan dan mengintegrasikan pengetahuan baru berdasarkan pengalamannya dalam beraktivitas secara nyata (Widyantini, 2014). Model project based learning memungkinkan peserta didik untuk melakukan aktivitas belajar saintifik berupa kegiatan bertanya, melakukan pengamatan, melakukan penyelidikan atau percobaan, menalar, dan menjalin hubungan dengan orang lain dalam upaya memperoleh informasi atau data. Model pembelajaran ini sangat sesuai dengan Permendikbud No 66 tahun 
2013 tentang Standar Penilaian, yang menyatakan bahwa untuk menilai kompetensi keterampilan dapat dilakukan melalui penilaian kinerja yang menuntut peserta didik mendemonstrasikan suatu kompetensi tertentu dengan menggunakan tes praktik, proyek dan penilaian portofolio.

Project based learning (PjBL) adalah model pembelajaran yang mengorganisasi kelas dalam sebuah proyek (Thomas, 2000). Menurut NYC Departement of Education (2009), PjBL merupakan strategi pembelajaran dimana siswa harus membangun pengetahuan konten mereka sendiri dan mendemonstrasikan pemahaman baru melalui berbagai bentuk representasi (hlm. 8). Menurut Nanang Hanafiah dan Cucu Suhana (2009) model pembelajaran Project Based Learning adalah pendekatan pembelajaran yang memperkenankan peserta didik untuk bekerja mandiri dalam mengkonstruksi pembelajarannya dan mengkulminasikannya dalam produk nyata. Sedangkan menurut Trianto (2014) Project Based Learning adalah sebuah model atau pendekatan pembelajaran yang inovatif, yang menekankan belajar kontekstual melalui kegiatan-kegiatan yang kompleks.

Menurut Made Wena (2014) model pembelajaran project based adalah model pembelajaran yang memberikan kesempatan kepada guru untuk mengelola pembelajaran dikelas dengan melibatkan kerja proyek. Cruickshank et. al (2006) menjelaskan bahwa pembelajaran berbasis proyek adalah strategi pembelajaran yang memberdayakan siswa untuk memperoleh pengetahuan dan pemahaman baru berdasar pengalamannya melalui berbagai presentasi. Sedangkan Olson (dalam Widyantini 2013) menjelaskan bahwa dalam pembelajaran berbasis proyek, siswa merencanakan dan melaksanakan penyelidikan terhadap beberapa topik atau tema yang menggunakan lintas mata pelajaran atau lintas materi. The National Council of Teachers of Mathematics (NCTM) Principles and Standards for School
Mathematics (2000) menjelaskan bahwa bahwa pembelajaran berbasis proyek mempunyai ciri-ciri bahwa siswa dapat memilih topik dan atau proyek presentasi/produk, menghasilkan produk akhir misal presentasi, rekomendasi untuk memecahkan masalah yang terkait dengan dunia nyata, melibatkan berbagai disiplin ilmu, bervariasi dalam durasi waktu, menampilkan guru dalam peran fasilitator.

Konstruktivis mengembangkan atmosfer pembelajaran yang menuntut peserta didik untuk menyusun sendiri pengetahuannya (Bell, 1995). Project based learning merupakan pendekatan pembelajaran yang memberikan kebebasan kepada peserta didik untuk merencanakan aktivitas belajar, melaksanakan proyek secara kolaboratif, dan pada akhirnya menghasilkan produk kerja yang dapat dipresentasikan kepada orang lain. Johnson \& Lamb (2007) menyatakan bahwa: project based learning focuses on creating a product or an artifact by using problem-based and inquiry-based learning depending on the depth of the driving question. Terdapat keterkaitan antara problem based learning (PBL) dan inquiry based learning (IBL). PBL berfokus pada solving real-world, dan pembelajaran inquiry berfokus pada problem-solving skills, sedangkan PjBL berfokus pada penciptaan proyek atau produk dalam membangun konsep.

Agar model pembelajaran project based learning menjadi menarik dan bermanfaat bagi peserta didik, model pembelajaran inidipadukan dengan etnomatematika. Etnomatematika menurut Shirley (dalam Rizka, 2014) adalah suatu ilmu yang digunakan untuk memahami bagaimana matematika diadaptasi dari sebuah budaya. Etnomatematika menggunakan konsep matematika secara luas yang terkait dengan berbagai aktivitas matematika, meliputi aktivitas mengelompokkan, berhitung, mengukur, merancang bangunan atau alat, bermain, menentukan lokasi, membuat grafik, maupun menggunakan alat peraga (Rachmawati, 2012). 
Pembelajaran

bermuatan etnomatematika sangat memungkinkan suatu materi yang dipelajari dari budaya mereka dapat membangkitkan motivasi belajar serta pemahaman suatu materi oleh peserta didik menjadi lebih mudah karena materi tersebut terkait langsung dengan budaya mereka yang merupakan aktivitas mereka sehari-hari dalam bermasyarakat.

Peran etnomatematika dalam model project based learning ini, peserta didik dapat mengenali dan menggunakan koneksi antara ide-ide matematika dalam menyelesaikan masalah proyek, mengkaitkan ide-ide matematika dan matematika dengan disiplin ilmu diluar matematika, dan matematika dengan dunia nyata dalam kehidupan sehari-hari. Dalam pembelajaran dilaksanakan proyekproyek yang berkaitan dengan budaya lokal. Contohnya pada materi lingkaran, peserta didik dapat membuat proyek misalnya berupa tamas atau tempeh yang merupakan salah satu budaya yang ada dilingkungan mereka (budaya Bali). Pada tamas dan tempeh tersebut terkandung unsur-unsur matematika berupa diameter, jari-jari, busur, luas dan keliling lingkaran. Contoh lain misalnya, penampang sokasi atau keben, maupun klatkat yang berbentuk persegi, kukusan dan kwangen yang berbentuk kerucut. Guru dapat mengemas pembelajaran dengan memanfaatkan unsur matematika ini dengan menyesuaikan pada topik yang dibahas. Semua hal itu merupakan kebudayaan masyarakat Bali yang perlu dilestarikan oleh generasi muda, setidaknya peserta didik mengetahui kebudayaan yang ada di sekitar mereka yang terkait dengan matematika.

Berdasarkan pencermatan terhadap materi dan proses penalaran yang digunakan dalam matematika dan uraian-uraian tentang hakekat matematika (the nature of mathematics) pada berbagai sumber antara lain Rees (1962), Courant (1964), Bell (1978, 1980), dan Stillwell (2004), dapat disimpulkan bahwa sifat-sifat matematika sebagai ilmu antara lain adalah sebagai berikut: 1) Konsep- konsep yang dibicarakan dalam matematika bersifat abstrak, misalnya konsep bilangan, konsep segitiga, konsep fungsi, dan sebagainya. 2) Konsep-konsep dan prinsip-prinsip matematika (aksioma-aksioma, teorema-teorema, dan sebagainya) tersusun secara hirarkis. 3) Proses penalaran yang digunakan dalam matematika adalah proses penalaran yang logis, dan terutama adalah proses penalaran deduktif. Proses penalaran deduktif adalah proses penalaran yang bertolak dari suatu aturan yang bersifat umum, kemudian aturan itu diterapkan dalam kasus-kasus yang spesifik. 4). Di dalam matematika digunakan cara untuk menyajikan konsep dan objek matematika yang lain secara efisien, antara lain dengan menggunakan lambang-lambang matematika. 5) Kebenaran suatu pernyataan dalam matematika didasarkan pada kesesuaian isi pernyataan itu dengan pernyataan-pernyataan lain yang sudah ada sebelumnya; atau, kalau pernyataan sebelum itu di anggap tidak ada, kebenaran pernyataan itu didasarkan pada asumsi bahwa pernyataan itu memang dianggap benar, yang disebut aksioma.

Apalagi pada Kurikulum 2006 dan Kurikulum 2013 yang menonjolkan peningkatan kemampuan peserta didik terhadap budaya dan pembelajaran yang berpusat pada peserta didik bukan berpusat pada guru.

Sangat sulit menanamkan pada peserta didik tentang pentingnya budaya yang ada di lingkungan sekitarnya, namun diharapkan dengan adanya model pembelajaran project based learning bermuatan etnomatematika peserta didiktidak mengalami kesulitan lagi memahami konsep-konsep matematika yang bisa digunakan dalam kehidupan sehari-hari. Sebab, secara tidak langsung peserta didik akan memahami dan mengetahui bahwa matematika bukanlah pelajaran yang menakutkan dan membosankan namun pelajaran yang menarik dan dapat dikaitkan dengan budaya tempat tinggal mereka. Jika model pembelajaran project based learning 
bermuatan etnomatematika ini diterapkan, maka akan mampu mengubah suasana belajar yang kaku menjadi aktif dan menyenangkan karena peserta didik akan termotivasi secara positif untuk aktif dalam proses pembelajarannya. Peserta didik lebih mudah memahami materi yang dipelajari karena dikaitkan dengan budaya mereka. Hal ini diperkuat oleh hasil penelitian Rizka, dkk. (2014) yang menunjukkan bahwa kontribusi model pembelajaran Project Based Learning bermuatan etnomatematika terhadap kemampuan koneksi matematika sebesar $85 \%$, tentunya nilai ini cukup besar berpengaruh terhadap hasil belajar matematika peserta didik.

Penelitian sangat bermanfaat bagi guru-guru yang mengampu mata pelajaran matematika terutama guru di SMP. Hasil penelitian ini dapat dijadikan rujukan dalam pembelajaran matematika yang menyenangkan dan memotivasi. Penelitian ini mampu menjawab kesulitan guru dalam mencari model pembelajaran yang tepat untuk meningkatkan hasil belajar matematika siswa.

Tujuan utama penelitian ini adalah untuk mengetahui perbedaan secara simultan motivasi belajar dan hasil belajar matematika antara peserta didik yang mengikuti model pembelajaran project based learning bermuatan etnomatematika dan peserta didik yang mengikuti model pembelajaran konvensional pada peserta didik kelas VIII SMP Negeri 3 Abiansemal tahun ajaran 2016/2017.

\section{METODE}

Penelitian ini merupakan jenis penelitian eksperimen semu (quasi eksperimen) yang mempunyai kelompok kontrol, tetapi tidak dapat berfungsi sepenuhnya untuk mengontrol variabel-variabel luar yang mempengaruhi pelaksanaan eksperimen (Sugiyono, 2015). Pada penelitian eksperimen ini, peneliti menggunakan dua kelompok sampel, yaitu kelompok perlakuan (kelompok eksperimen) dan kelompok kontrol. Penelitian ini menggunakan desain penelitian non equivalen post-test-only control group design. Adapun rancangan penelitian ini disajikan pada Gambar 1.

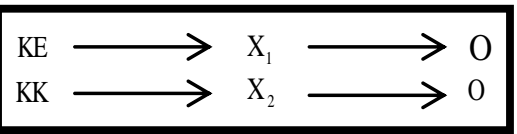

Gambar 1. Desain penelitian non equivalen post-test-only control group design

Penelitian dilakukan selama satu setengah bulan, yaitu pada semester satu tahun ajaran 2016/2017, mulai bulan Agustus sampai dengan Oktober 2016. Populasi dalam penelitian ini adalah seluruh peserta didik kelas VIII SMP Negeri 3 Abiansemal yang terdiri dari 16 kelas dengan peserta didik sebanyak 573 orang dan melibatkan sampel sebanyak 71 orang yang diambil dengan teknik simple random sampling. Ada dua jenis instrumen yang digunakan untuk menjaring data, yaitu angket motivasi belajar dan tes hasil belajar matematika. Data yang terkumpul kemudian dianalisis menggunakan statistik parametrik berupa MANOVA, namun sebelumnya dilakukan uji prasyarat, yaitu: uji normalitas sebaran data dan uji homogenitas varians.

\section{HASIL DAN PEMBAHASAN}

Hasil uji hipotesis menunjukkan bahwa terdapat perbedaan secara simultan motivasi dan hasil belajar matematika peserta didik yang mengikuti model pembelajaran project based learning bermuatan etnomatematika dengan peserta didik yang mengikuti model pembelajaran konvensional. Berdasarkan hasil analisis nilai multivariate tests menunjukkan bahwa nilai $\mathrm{F}_{\text {hitung }}$ untuk Pillai's trace, Wilks Lamda, Hotelling's Trace, Roy's Largest Root memiliki signifikansi yang kurang dari 0,05 atau $0,0001<0,005$. Hal ini menunjukkan bahwa terdapat perbedaan secara simultan motivasi belajar dan hasil belajar matematika peserta didik yang 
mengikuti model pembelajaran project based learning bermuatan etnomatematika dengan peserta didik yang mengikuti model pembelajaran konvensional. Lebih jauh dapat dilihat rata-rata motivasi belajar dan hasil belajar matematika kelompok eksperimen lebih tinggi daripada ratarata motivasi belajar dan hasil belajar matematika kelompok kontrol, yaitu masing-masing sebesar 58,80 dan 75,71 untuk kelompok eksperimen serta 55,19 dan 68,39 untuk kelompok kontrol. Hasil analisis ini mengindikasikan bahwa model pembelalaran project based learning bermuatan etnomatematika memiliki keunggulan dibandingkan dengan model pembelajaran konvensional.

Temuan hasil pengamatan selama proses pembelajaran sejalan dengan pendapatnya Ambarawati dkk (2015) dan Edy (2013) yaitu menemukan bahwa beberpa keunggulan model pembelajaran project based learning bermuatan etnomatematika dibandingkan dengan model pembelajaran konvensional adalah a) menjadi media yang mudah dimengerti dalam penyampaiaan konsep-konsep matematika, b) matematika menjadi lebih realistik sehingga mudah diterima oleh peserta didik, c) muatan etnomatematika (melalui observasi) menjadikan motivasi siswa belajar matematika meningkat, d) kemampuan peserta didik dalam berkolaborasi meningkat, e) mendorong peserta didik mempraktikkan keterampilan berkomunikasi dan bernalar, f) memberikan pengalaman kepada peserta didik dalam mengorganisasikan proyek, mengalokasikan waktu, dan mengelola sumber daya seperti peralatan dan bahan untuk menyelesaikan tugas, g) melibatkan peserta didik untuk belajar mengumpulkan informasi dan menerapkan sekaligus memperkenalkan kebudayaan kepada peserta didik, serta h) membuat suasana belajar menjadi menyenangkan dan peserta didik menjadi aktif, sehingga peserta didik maupun guru menikmati proses pembelajaran

Melalui proyek matematika yang diberikan, peserta didik menjadi lebih tertarik untuk berdiskusi dan mengerjakan proyek yang diberikan, karena konsep-konsep matematika yang dijadikan proyek sangat dekat dengan kehidupan mereka bahkan setiap hari mereka jumpai. Model pembelajaran berbasis proyek semakin memiliki keunggulan dibandigkan dengan model pembelajaran konvensional ketika dipadukan dengan etnomatematika. Kolaborasi antara model pembelajaran dengan unsur budaya Bali melalui etnomatematika membuat peserta didik semakin tertarik mempelajari matematika. Mereka akhirnya mengetahui dan menyadari bahwa matematika sangat berperan dalam kehidupan terutamnya dalam budaya Bali. Sebagai sebuah ilustrasi, ketika peserta didikdiberikan proyek berkaitan dengan lingkaran, beberapa kelompok peserta didikmembawa "tamas" ke dalam kelas untuk lebih memperjelas hasil kerja kelompoknya dan presentasi mengenai unsur-unsur lingkaran. Dari pertama kali membuat tamas (dalam lingkaran potonganpotongan pembentuk tamas tersebut merupakandiameter), sampai menjarit satu demi satu, sampai memberikan pinggiran (sibeh) yang merupakan keliling lingkaran.

Dengan pembelajaran seperti ilustrasi di atas, pembelajaran di kelas semakin menarik. Peserta diddik akan semakin termotivasi untuk belajar karena mereka tidak hanya belajar tentang materi matematika tetapi juga belajar tentang budaya mereka, yaitu budaya Bali utamanya mejejaitan. Dari pembelajaran yang diterapkan mereka juga menghasilkan sebuah produk jejaitan, yang tentunya dalam pengerjaanya membutukan konsepkonsep dalam matematika. Pembelajaran akan menjadi lebih bermakna, dalam artian peserta didik mengetahui manfaat belajar matematika dalam kehidupan nyata. Jadi belajar matematika tidak hanya belajar untuk menghadapi ujian tetapi lebih dari itu, 
belajar untuk digunakan dalam kehidupan sehari-hari. Adanya produk nyata tersebut akan mendorong peserta didik untuk berkreativitas (Titu, 2015).

Hasil penelitian penelitian Tien, dkk (2016) semakin mengukuhkan keunggulan model pembelajaran project based learning bermuatan etnomatematika dibandingkan model pembelajaran konvensional. Hasil penelitian tersebut menunjukkan bahwa model pembelajaran project based learning mampu meningkatkan kemampuan berpikir kreatif dan komunikasi matematis siswa. Kemampuan komunikasi matematika merupkan salah satu unsur yang menentukan hasil belajar matematika. Tidak heran kalau motivasi belajar dan hasil belajar matematika siswa yang mengikuti pembelajaran dengan model pembelajaran project based learning bermuatan etnomatematika lebih baik dibandingkan dengan motivasi belajar dan hasil belajar matematika peserta didik yang mengikuti pembelajaran dengan model pembelajaran konvensional.

\section{SIMPULAN DAN SARAN}

Dari hasil uji hipotesis diperoleh hasil bahwa terdapat perbedaan secara simultan motivasi belajar dan hasil belajar matematika peserta didik yang mengikuti model pembelajaran project based learning bermuatan etnomatematika dengan peserta didik yang mengikuti model pembelajaran konvensional pada peserta didik kelas VIII SMP Negeri 3 Abiansemal Tahun Ajaran 2016/2017. Sehingga dapat disimpulkan bahwa terdapat pengaruh yang signifikan model pembelajaran project based learning bermuatan etnomatematika terhadap motivasi belajar dan hasil belajar matematika peserta didik kelas VIII SMP Negeri 3 Abiansemal Tahun Ajaran 2016/2017. Disarankan kepada guru matematika SMP untuk menerapakan model pembelajaran project based learning bermuatan etnomatematika dalam pembelajarannya untuk memperoleh hasil belajar yang lebih optimal.

\section{DAFTAR PUSTAKA}

Ambarwati. (2015). Keefektifan Model Project Based Learning Berbasis GQM Terhadap Kemampuan Komunikasi Matematis dan Percaya Diri Siswa Kelas VII. Journal of Mathematics Education Vol. 4(2). Unnes.

Fitriana, Tien. (2016). Peningkatan kemampuan berpikir kreatif dan komunikasi matematis siswa SMA melalui pembelajaran project based learning berbasis debat. Jurnal Didaktik Matematika. Volume 3, Nomor 1, April 2016. Unsyah, Banda Aceh.

Ismayani, Ani, Nuryanti. (2016). Penerapan Project Based Learning dalam Pembelajaran Matematika untuk Meningkatkan Kemampuan Komunikasi Matematis dan Aktivitas Belajar Siswa. Prosiding. ISSN: 25026526 Maret 2016. [Online]. Tersedia: http://publikasiilmiah .ums.ac.id/handle/11617/7015.

Rachmawati, Inda. (2012). Eksplorasi Etnomatematika Masyarakat Sidoarjo. Ejournal Unnes.

Rizka S. (2014). Model Project Based Learning Bermuatan Etnomatematika Untuk Meningkatkan Kemampuan Koneksi Matematika. Unnes Journal of Mathematics Education Research.

Sugiyono. (2015). Metode Penelitian Pendidikan Pendekatan Kuantitatif, Kualitatif, dan R\&D. Bandung: Alfabeta.

TIMSS. (2015). Trend in International Mathematics and Science Study (TIMSS)

2015

Results.http://nces.ed.gov/pubs20 17/2017002 timss 2015_results.pdf

Titu, Maria Anita. (2015). Penerapan model pembelajaran project based learning (PjBL) untuk meningkatkan kreativitas siswa pada materi konsep masalah ekonomi. Prosiding Nasional. UNY Mei 2015.

Widyantini, Theresia. (2014). Penerapan Model Project Based 
Learning (Model Pembelajaran berbasis Proyek) dalam materi Pola Bilangan Kelas VII. Artikel Pusat Pengembangan dan pemberdayaan Pendidikan tenaga Kependidikan Matematika 2014.

Lampiran Undang-Undang Repbublik Indonesia No. 20 tahun 2003 tentang Sistem Pendidikan Nasional. Jakarta: Mendikbud.

Lampiran Peraturan Menteri Pendidikan dan Kebudayaan No. 66 tahun 2013 tentang Standar. Jakarta: Mendikbud

Stillwell, John. (2004). Mathematics and Its History (Second Edition). New York: Springer.

Rees, Mina. (1962). The nature of mathematics. The Mathematics Teacher, October: 434-440.

Courant, Richard. (1964). Mathematics in the modern world. Dalam Mathematics in the Modern World: Readings from Scientific Americans. San Franscisco: W.H. Freeman \& Company.

Bell, Frederick H. (1978). Teaching and Learning Mathematics (in Secondary Schools). Dubuque, lowa: Wm.C. Brown.

Bell, Frederick H. (1980). Teaching Elementary School Mathematics: Methods and Content for Grades K-8. Dubuque, lowa: Wm.C. Brown.

Thomas, J.W. (2000). A Review of Research on Project Based Learning. California: The Autodesk Foundation.

NYC Departement of Education (2009). Project Based Learning: Inspiring Middle School Student to Engage in Deep and Active Learning. New York: Division of Teaching and Learning Office

Cook, et al. (2012). Preparing Biology Teachers to Teach Evolution in a Project-Based Approach. Winter vol. 21 no. 2 : $18-30$

Thomas, J.W. (2000). A Review of Research on Project Based Learning. California: The Autodesk Foundation
Bell, B.F. (1995). Children's Science, Contructivism and learning in science. Victoria: Deakin University Pers.

Cruickshank, D.R., Jenkins, D.B., \& Metcalf, K.K. (2006). The act of teaching, 4 Thedition, NY: Mc Graw Hill http://edukasielektro.blogspot.co m/2013/05/pembelajaranberbasis-proyek.html diakses tgl 14 agustus 2013

Widyantini, Untung TS, Joko $\mathrm{P}$ dan Estina E. (2013). Laporan Penelitian Pengembangan Model Pembelajaran Project Based Learning(PjBL) dalam Pembelajaran Matematika. PPPPTK matematika: Yogyakarta

Made Wena. (2009). Strategi pembelajaran inovatif kontemporer: suatu tinjauan konseptual operasional. Jakarta: Bumi Aksara.

Nanang Hanafiah \& Cucu Suhana. (2009). Konsep strategi pembelajaran. Bandung: PT. Refika Aditama.

Trianto Ibnu Badar Al-Tabani. (2014) Mendesain model pembelajaran inovatif, progresif, dan kontekstual. Jakarta: Prenadamedia Group. 